\title{
Fractionation and Physicochemical Studies of AcaciaSenegal Gums
}

\author{
A. A. Osman ${ }^{1}$, M. H. A. Suleiman'2 M. E. Osman ${ }^{3}$, E. A. Hassan ${ }^{4}$ \\ ${ }^{1}$ Bisha University, College of Science and Home economic, Department of Chemistry, Kingdom of Saudi Arabia \\ ${ }^{2}$ King Khalid University, Faculty of Science, Department of Chemistry,Abha, Kingdom of Saudi Arabia \\ ${ }^{3,4}$ Sudan university of Science and Technology, College of Science, Department of Chemistry, Khartoum, Sudan
}

\begin{abstract}
The chemical and physicochemical characteristics of five authenticated A. senegal gum samples from trees of varying age have been investigated. A. senegal was fractionated by a successive non-solvent fractionation technique using ethanol and acetone as a fractionation agent separately. The fractions were found to be different from the whole gum in terms of molecular characteristics. The molecular mass distribution was determined by gel permeation chromatography (GPC-MALLS) with on-line monitoring using light scattering, refractive index and $U V$ absorbance detectors. The result shows that three main component designated arabinogalactane protein (AGP), arabinogalactane (AG) and glycoprotein (GP) known to be present in A. senegal could be present in their fractions. The weight average molecular weight of $A$. senegal ranged from $0.808-1.334 \mathrm{X} 10^{6} \mathrm{~g} /$ molwith $_{M_{w}} / M_{n}$ ranged from (2.89-4.42). The SG4 $15-20$ sample that from the 10-15 years old tree shows high molecular weight, high viscosity and produce emulsion which were stable under accelerate stress condition. All ethanol fractions and ( SG-F1A and SG-F3A) gave the best emulsification performance and stability than the starting material (SG-control) dependent on the protein distribution and its association with the high molecular weight fraction (AGP). All emulsion of ethanol and acetone fractions of A. senegal show low degrees of polydispersity and droplet size compared to the starting material indicating uniformity, clean fractionation and increased adsorption of protein on the oil droplet surface.
\end{abstract}

Keywords: Acacia senegal, Gum Arabic, Fractionation, Emulsion stability, droplet size, molecular weight

\section{Introduction}

Gum Arabic is a heterogeneous complex polysaccharide that consists of carbohydrate polymer (composed of galactose $(44 \%)$, rhamnose $(13 \%)$, arabinose $(27 \%)$, glucuronic acid and 4-O-methyl glucuronic acid (16\%), and small amount of proteinaceous materials $(\sim 2 \%)$ [1].

The gum from $A$. senegal has been studied by many workers [2-4] and It has been found to have core $\beta(1>3)$ and $(1>6)$ linked D-galactopyranose with branches at $0-6$ on the $(1>3)$ linked residues. The branches consist of L-arabinofuranose, L-arabinopyranose, L-rhamnose and D-glucuronopyranose. It also contains about $2 \%$ proteinaceous material which forms an integral part of the structure. The gum consists of a spectrum of molecular species but three distinct components have been recognized following fractionation using hydrophobic affinity chromatography [5].The main component, which corresponds to about $90 \%$ of the total, has a molecular mass and $\mathrm{Rh}$ of $\sim 2.5 \times 10^{5}$ and $\sim 9 \mathrm{~nm}$ respectively and contains very little protein. A second component $(\sim 10 \%$ of the total) has a molecular mass and $\mathrm{Rh}$ of $>1 \times 10^{6}$ and $\sim 23 \mathrm{~nm}$ contain $\sim 10 \%$ protein, which comprises mainly of hydroxyproline, proline and serine. It can be degraded by proteolytic enzyme into smaller fragments of molecular mass $\sim 2-3 \times 10^{5}$ and hence it has been argued that it has a wattle blossom-type structure typical of arabinogalcatan protein complexes, where large carbohydrate blocks $\left(2-3 \times 10^{5}\right)$ are attached to a common polypeptide chain [6-8]. Anderson and Stoddart[9] obtained a value of $5 \times 10^{5}$ and $8.5 \times 10^{5}$ for the number average molecular weight (Mn) using molecular sieve chromatography and for weight average molecular weight $\left(\mathrm{M}_{\mathrm{w}}\right)$ using light scattering technique for A.senegalgum. Cannoly et al. [10] calculated the molecular mass of the blocks of $A$. senegal gum and found it to be of the order $2 \times 10^{5}$.Duvallet et al. [11] reported value of $7.2 \times 10^{5}$ for molecular weight of $A$. senegal gum using low angle laser light scattering technique in $\mathrm{IM} \mathrm{NaCl}$ at $25.0^{\circ} \mathrm{C}$, they also obtained the value of $1.9 \times 10^{5}$ for the number average molecular weight $(\mathrm{Mn})$ using osmometry determination in $0.01 \mathrm{M} \mathrm{NaCl}$ at $37.0^{\circ} \mathrm{C}$. Using GPC-MALLS, Idris et al. [12] obtained values between $2 \times 10^{5}$ and $7.9 \times 10^{5}$ of the weight average molecular weight and values between $1.6 \times 10^{5}$ and $4.5 \times 10^{5}$ of the number average molecular weight (Mn) for A. senegalgum. Al-Assaf et al. [13] reported a value of 5.99 x $10^{5}$ for the weight average molecular weight using GPCMALLS of $A$. senegaland a value of $10.4 \times 10^{5}$ for $A$. seyal.

Polysaccharide hydrocolloids, such as gums, stabilize emulsionsprimarily by increasing the viscosity, slowing the thermodynamically favored breakdown of the emulsion but may also act as emulsifiers, where their emulsion ability is reported as mainly, being due to accompanying, contaminating or intrinsic, protein moieties[14, 15]. In particular, electrostatic interaction between ionic hydrocolloids and proteins may give rise to marked emulsification ability with considerable stability so long as the $\mathrm{pH}$ and ionic strength are controlled[16]. Hydrocolloids may interact with other food components such as aiding the emulsification of fats, stabilizing milk protein micelles or affecting the stickiness of gluten. Prakashet al. [5]studied the addition of whey proteins on the functionality of gum Arabic in soft drink emulsions and reported that the addition of small amount whey protein increase in the emulsion activity index. Randall et al. [3] studied the role of the proteinaceous component on the emulsification properties of gum Arabic and reported that only $1-2 \%$ of the gum Arabic adsorbed at oil-water interface and that the high molecular mass, protein rich fraction is responsible for the emulsification properties

\section{Volume 4 Issue 12, December 2015}




\section{International Journal of Science and Research (IJSR) \\ ISSN (Online): 2319-7064 \\ Index Copernicus Value (2013): 6.14 | Impact Factor (2014): 5.611}

of gum Arabic as a whole[3]. However the emulsification properties of gums are well reported in literature [17-20].

\section{Material and Methods}

Acaciasenegal gum samples were collected by one of the authors from Kordofan state, western Sudan. Acaciasenegal tree season 2007-2008 of particular ages 5-9, 10-15 and 1620 years were labeled from $\mathrm{SG}_{5-9}-\mathrm{SG} 5_{16-20}$ to designate the $A$. senegalgum samples. The subscripted number refers to the ages of the tree.

The physicochemical properties of the gum and fractions such as moisture, ash, specific rotation, intrinsic viscosity, equivalent weight, molecular weight and protein content were determined using standard method[21-23]. Average number molecular weight determination of $A$. senagalgum samples and their fractions were determined using the GPC system, comprising a high precision HPLC pump (Water, USA), an injector (Rheodyne 7125, Rheodyne, UK), a GPC column (Sepharose 6, Pharmacia, Sweden) attached to a multi-angle laser light scattering system (DAWN DSP, Wyatt Technology USA), UV detector (PyeUnicam, UK), and the software (Astra 4.5 for windows, Wyatt Technology, USA) were arranged. The system is switched on for two hour to equilibrate before carrying out any analysis. Gum samples were accurately weight $0.02 \mathrm{~g}$ in small vial $\mathrm{NaCl}$ to which $5 \mathrm{ml}$ of $0.2 \mathrm{M}$ were then added. The vials were stoppered and kept on a roller shaker for two hours. 100microlitre solution was injected into the GPC system via $0.45 \mu \mathrm{m}$ filter (Water Millipore) into the injector fitted with 100 -microlitre loop. Elution buffer, $0.2 \mathrm{M} \mathrm{NaCl}$, was passed at flow rate of $0.5 \mathrm{~cm}^{3} / \mathrm{min}$ at ambient temperature. The gum was fractionated while passing through the Sepharose 6 GPC column and fractions were detected via MALLS, RI and UV detectors responses were collected and analyzed in real time by the computer software $[3,12,14]$.

The droplet size of emulsion immediately after preparation (initial) was measured using laser diffraction (Mastersizer 2000, Malven UK). Emulsification effectiveness was evaluated based on the initial particle size of the emulsion. The emulsion stability was evaluated by the change in particle size after acceleration test ( 3 and 7 days storage at $60{ }^{\circ} \mathrm{C}$ ) was taken as a parameter to designate the category/ grade of the gum sample.

\section{Results and Discussion}

\subsection{Characterization of A.senegalgum and their fractions:}

The variation of physicochemical properties of $A$. senegal gum with trees age ranged from 5-20 years old. The highest values of moisture, intrinsic viscosity and acid equivalent weight were that of sample SG4 $4_{10-15}$ that obtained from 1015 years old tree. This result coincides with those reported by other Co-workers[25, 26]. Whilst the highest values of specific rotation, number average molecular weight and protein content was obtained by sample $\mathrm{SG}_{5-9}$ that picked from 5-9 years old tree (Table 1).

Table 1: Analytical data of the gum exudates from $A$. senegal samples

\begin{tabular}{|c|c|c|c|c|c|c|c|c|c|}
\hline $\begin{array}{l}\text { Sample } \\
\text { code }\end{array}$ & $\begin{array}{l}\text { Ash } \\
(\%)\end{array}$ & $\begin{array}{c}\text { Moisture } \\
\text { (\%) }\end{array}$ & $\begin{array}{r}{[\alpha]_{\mathrm{D}}^{25}} \\
\operatorname{deg}\end{array}$ & A.E.W & $\begin{array}{c}\text { Glucouronic } \\
\text { acid }\end{array}$ & $\begin{array}{c}\text { Nitrogen } \\
(\%)\end{array}$ & $\begin{array}{l}\text { protein } \\
(\%)\end{array}$ & $\begin{array}{c}\mathrm{M}_{\mathrm{n}} \mathrm{X} \mathrm{10} \mathbf{1 0}^{5} \\
\mathrm{~g} / \mathrm{mol}\end{array}$ & $\begin{array}{l}{[\eta]} \\
\mathrm{ml} / \mathrm{g}\end{array}$ \\
\hline SG1 5-9 & 5.10 & 11.42 & $-33^{\circ}$ & 1135 & 17.09 & 0.43 & 2.86 & 2.22 & 19.07 \\
\hline SG2 $_{5-9}$ & 5.23 & 10.60 & $-29^{\circ}$ & 1703 & 11.39 & 0.36 & 2.40 & 1.63 & 18.67 \\
\hline $\mathrm{SG3}_{16-20}$ & 5.07 & 9.91 & $-30^{\circ}$ & 1472 & 13.18 & 0.36 & 2.37 & 1.96 & 18.65 \\
\hline SG4 $_{10-15}$ & 5.06 & 14.72 & $-30^{\circ}$ & 1773 & 11.17 & 0.30 & 1.99 & 1.16 & 19.14 \\
\hline SG5 $_{16-20}$ & 4.00 & 11.01 & $-31^{\circ}$ & 1620 & 11.96 & 0.28 & 1.82 & 1.02 & 18.84 \\
\hline
\end{tabular}

The physicochemical properties of ethanol and acetone fractions obtainable by successive solvent fractionation of A.senegalgum are given in (Table 2). There is no difference in ash, moisture, optical rotation of all fractions except SGF2A which show optical rotation $\left(-16^{\circ}\right)$. The protein content of ethanol fraction was much higher than acetone fractions, whilst SG-F2E, SG-F4E and SG-F5E contains protein higher than the starting material. The viscosities of ethanol fractions are higher than the acetone fractions and less than the viscosity of starting material (SG-control).

The molecular weight was measured for the whole gum as two peaks; the first peak (which corresponds to the AGP) and the second peak (which corresponds to the AG andGP) as identified by the refractive index detector. The summary of the molecular weights parameters of all A. senegal samples are given in (Table 3).

Table 2: Analytical data of the ethanol and acetone fractions of $A$. senegal

\begin{tabular}{|c|c|c|c|c|c|c|c|c|c|c|}
\hline $\begin{array}{c}\text { Fractions } \\
\text { Code }\end{array}$ & $\begin{array}{c}\text { Yield } \\
\%\end{array}$ & $\begin{array}{c}\text { Ash } \\
\%\end{array}$ & $\begin{array}{c}\text { Moisture } \\
\%\end{array}$ & $\begin{array}{c}{[\alpha]_{\mathrm{D}}^{25}} \\
\mathrm{deg}\end{array}$ & A. E. W & $\begin{array}{c}\mathrm{M}_{\mathrm{n}} \mathrm{X} 10^{5} \\
\mathrm{~g} \text { mol }\end{array}$ & $\begin{array}{c}\text { Nitrogen } \\
\%\end{array}$ & $\begin{array}{c}\text { protein\% } \\
\text { \% }\end{array}$ & $\begin{array}{c}\text { Glucouronic } \\
\text { Acid \% }\end{array}$ & $\begin{array}{c}{[\eta] \mathrm{ml} / \mathrm{g}} \\
\text { SG-Control }\end{array}$ \\
\hline SG -F1E & 39.60 & 5.41 & 11.33 & $-33^{\circ}$ & 1711 & 1.75 & 0.33 & 2.21 & 16.01 & 19.23 \\
\hline SG- F2E & 20.50 & 5.48 & 11.52 & $-30^{\circ}$ & 521 & 0.082 & 0.35 & 2.28 & 36.72 & 14.63 \\
\hline SG- F3E & 16.20 & 5.96 & 10.73 & $-23^{\circ}$ & 457 & 0.012 & 0.34 & 2.21 & 41.33 & 11.98 \\
\hline SG- F4E & 04.9 & 5.63 & 10.38 & $-26^{\circ}$ & 620 & 0.041 & 0.39 & 2.60 & 31.29 & 14.35 \\
\hline SG- F5E & 01.20 & 5.01 & 12.05 & $-30^{\circ}$ & 218 & 0.018 & 0.41 & 2.73 & 80.91 & 14.08 \\
\hline SG -F1A & 34.10 & 5.62 & 10.80 & $-28^{\circ}$ & 939 & 0.014 & 0.32 & 2.13 & 20.67 & 13.76 \\
\hline SG -F2A & 19.20 & 4.55 & 9.71 & $-16^{\circ}$ & 1708 & 0.015 & 0.25 & 1.67 & 11.37 & 13.35 \\
\hline
\end{tabular}




\section{International Journal of Science and Research (IJSR) \\ ISSN (Online): 2319-7064}

Index Copernicus Value (2013): 6.14 | Impact Factor (2014): 5.611

\begin{tabular}{|l|l|l|l|l|l|l|l|l|l|l|}
\hline SG- F3A & 08.50 & 5.83 & 9.70 & $-23^{\circ}$ & 1502 & 0.012 & 0.32 & 2.11 & 12.92 & 11.98 \\
\hline SG- F4A & 04.70 & 6.51 & 9.07 & $-27^{\circ}$ & 815 & 0.018 & 0.29 & 1.89 & 23.79 & 14.39 \\
\hline SG- F5A & 01.40 & 6.13 & 9.09 & $-27^{\circ}$ & 834 & 0.032 & 0.27 & 1.81 & 23.26 & 11.69 \\
\hline
\end{tabular}

Table 3: Molecular weight parameter of A.senegal samples (GPC-MALLS).

\begin{tabular}{|c|c|c|c|c|c|c|c|c|}
\hline Sample code & $\begin{array}{c}M_{w} \text { processed as } \\
\text { one peak }\end{array}$ & $\begin{array}{c}\% \\
\text { mass }\end{array}$ & $\begin{array}{l}\text { Rg } \\
(\mathbf{n m})\end{array}$ & $\mathbf{M}_{\mathbf{w}} / \mathbf{M}_{\mathbf{n}}$ & $\begin{array}{c}M_{w} \text { processed as } \\
\text { two peak }\end{array}$ & $\begin{array}{c}\% \\
\text { mass } \\
\end{array}$ & $\begin{array}{c}\mathrm{Rg} \\
(\mathrm{nm})\end{array}$ & $\mathbf{M}_{\mathbf{w}} / \mathbf{M}_{\mathbf{n}}$ \\
\hline \multirow[t]{2}{*}{ SG1 $_{5-9}$} & $0.808 \times 10^{6}$ & 102 & 60.1 & $3.308 \pm 0.239$ & $4.146 \times 10^{6}$ & 12.2 & 63.2 & $1.705 \pm 0.139$ \\
\hline & & & & & $0.341 \times 10^{6}$ & 87.8 & 54.2 & $1.570 \pm 0.075$ \\
\hline \multirow[t]{2}{*}{ SG2 $_{5-9}$} & $0.846 \times 10^{6}$ & 94.5 & 54.5 & $3.604 \pm 0.290$ & $9.905 \times 10^{6}$ & 11.0 & 68.0 & $1.797 \pm 0.109$ \\
\hline & & & & & $0.335 \times 10^{6}$ & 89.0 & 0.0 & $1.592 \pm 0.113$ \\
\hline \multirow[t]{2}{*}{ SG3 $_{16-20}$} & $0.966 \times 10^{6}$ & 94.4 & 65.7 & $3.730 \pm 0.250$ & $3.958 \times 10^{6}$ & 16.1 & 75.5 & $1.522 \pm 0.087$ \\
\hline & & & & & $0.375 \times 10^{6}$ & 83.6 & 37.8 & $1.705 \pm 0.093$ \\
\hline \multirow[t]{2}{*}{ SG4 $_{10-15}$} & $1.334 \times 10^{6}$ & 91.2 & 55.7 & $4.920 \pm 0.367$ & $6.374 \times 10^{6}$ & 13.8 & 54.7 & $1.390 \pm 0.040$ \\
\hline & & & & & $0.425 \times 10^{6}$ & 86.2 & 58.5 & $1.832 \pm 0.144$ \\
\hline \multirow[t]{2}{*}{ SG5 $_{16-20}$} & $0.946 \times 10^{6}$ & 102.9 & 39.9 & $2.885 \pm 0.092$ & $3.720 \times 10^{6}$ & 15.7 & 45.3 & $1.358 \pm 0.036$ \\
\hline & & & & & $0.409 \times 10^{6}$ & 84.3 & 27.7 & $1.460 \pm 0.044$ \\
\hline
\end{tabular}

The weight average molecular weights of $A$. senegal samples ranged from $1.335 \times 10^{6}$ to $8.078 \times 10^{5} \mathrm{~g} / \mathrm{molwith}$ the mass recovery 94.5 to $102.6 \%$. The AGP component was found to be in the range of 11.0 to 15.7 of the total of the gum with the molecular weight range of $3.720 \times 10^{5}$ to $9.905 \times 10^{6} \mathrm{~g} / \mathrm{mol}$. The result shows that the high molecular weight was found in the sample SG4 ${ }_{10-15}$ that from the 1015 years old tree The result agrees with Anderson et al. [28] who noted that the gum from trees between 10 and 15 of age had the highest molecular weight and viscosity; they also noted that the most viscous sample had average nitrogen content, although high nitrogen content did not necessarily imply high viscosity. The molecular weight parameters and
AGP component of ethanol and acetone fractions of $A$. senegal are shown in (Table 4). Ethanol fractions of $A$. senegal have average molecular weight and AGP component higher than the starting material. The above result indicating that all ethanol fractions have a good emulsifying property and stability compared to the starting material (SG-control) while acetone fraction (SG-F2A, SG-F4A and SG-F5A) have a higher molecular weight and low protein content than the starting material, indicating that these fractions have a poor emulsifying property and stability than the starting material (SG-control).

Table 4: Molecular weight parameter of ethanol and acetone fractions of A.senegal(GPC-MALLS).

\begin{tabular}{|c|c|c|c|c|c|c|c|c|}
\hline $\begin{array}{l}\text { Sample } \\
\text { code }\end{array}$ & $\begin{array}{c}\mathbf{M}_{\mathrm{w}} \text { processed } \\
\text { as one peak }\end{array}$ & $\begin{array}{c}\% \% \\
\text { mass }\end{array}$ & $\begin{array}{c}\mathrm{Rg} \\
(\mathrm{nm})\end{array}$ & $\mathbf{M}_{\mathbf{w}} / \mathbf{M}_{\mathbf{n}}$ & $\begin{array}{c}M_{w} \text { processed as } \\
\text { two peak }\end{array}$ & $\begin{array}{c}\% \\
\text { mass }\end{array}$ & $\begin{array}{c}\mathrm{Rg} \\
(\mathrm{nm})\end{array}$ & $\mathbf{M}_{\mathbf{w}} / \mathbf{M}_{\mathbf{n}}$ \\
\hline \multirow[t]{2}{*}{ SG-control } & $1.135 \times 10^{6}$ & 102.6 & 32.1 & $3.697 \pm 0.298$ & $4.783 \times 10^{6}$ & 14.1 & 56.1 & $1.832 \pm 0.071$ \\
\hline & & & & & $4.264 \times 10^{5}$ & 73.0 & 24.9 & $1.626 \pm 0.211$ \\
\hline \multirow[t]{2}{*}{ SG-F1E } & $1.708 \times 10^{6}$ & 103.6 & 24.9 & $3.847 \pm 0.690$ & $6.635 \times 10^{6}$ & 20.4 & 49.8 & $2.616 \pm 0.501$ \\
\hline & & & & & $4.436 \times 10^{5}$ & 79.6 & 11.9 & $1.211 \pm 0.184$ \\
\hline \multirow[t]{2}{*}{ SG-F2E } & $1.681 \times 10^{6}$ & 116.4 & 24.4 & $6.456 \pm 0.090$ & $1.074 \times 10^{6}$ & 12.8 & 49.8 & $3.821 \pm 0.645$ \\
\hline & & & & & $3.527 \times 10^{5}$ & 87.2 & 17.8 & $1.535 \pm 0.235$ \\
\hline \multirow[t]{2}{*}{ SG-F3E } & $2.209 \times 10^{6}$ & 110.3 & 27.4 & $5.133 \pm 0.290$ & $1.086 \times 10^{6}$ & 16.5 & 50.3 & $2.821 \pm 0.151$ \\
\hline & & & & & $4.948 \times 10^{5}$ & 83.5 & 20.0 & $1.352 \pm 0.074$ \\
\hline \multirow[t]{2}{*}{ SG-F4E } & $1.815 \times 10^{6}$ & 106.0 & 23.1 & $4.227 \pm 0.207$ & $8.373 \times 10^{6}$ & 16.7 & 45.7 & $2.347 \pm 0.117$ \\
\hline & & & & & $4.948 \times 10^{5}$ & 83.4 & 14.8 & $1.356 \pm 0.046$ \\
\hline \multirow[t]{2}{*}{ SG-F5E } & $1.542 \times 10^{6}$ & 112.3 & 24.9 & $4.673 \pm 0.213$ & $7.736 \times 10^{6}$ & 15.7 & 49.0 & $2.711 \pm 0.121$ \\
\hline & & & & & $3.905 \times 10^{5}$ & 84.7 & 16.9 & $1.378 \pm 0.050$ \\
\hline \multirow[t]{2}{*}{ SG-F1A } & $1.216 \times 10^{6}$ & 114.1 & 60.0 & $3.409 \pm 0.131$ & $5.579 \times 10^{6}$ & 15.3 & 69.2 & $1.720 \pm 0.062$ \\
\hline & & & & & $4.252 \times 10^{5}$ & 84.7 & 27.8 & $1.384 \pm 0.044$ \\
\hline \multirow[t]{2}{*}{ SG-F2A } & $1.262 \times 10^{6}$ & 107.6 & 83.4 & $5.507 \pm 0.376$ & $11.22 \times 10^{6}$ & 8.4 & 95.8 & $3.044 \pm 0.242$ \\
\hline & & & & & $3.494 \times 10^{5}$ & 91.7 & 20.4 & $1.656 \pm 0.055$ \\
\hline \multirow[t]{2}{*}{ SG-F3A } & $1.432 \times 10^{6}$ & 105.5 & 85.0 & $3.984 \pm 0.253$ & $8.258 \times 10^{6}$ & 11.6 & 67.2 & $1.750 \pm 0.066$ \\
\hline & & & & & $4.841 \times 10^{5}$ & 88.4 & 116.9 & $1.520 \pm 0.152$ \\
\hline \multirow[t]{2}{*}{ SG-F4A } & $1.783 \times 10^{6}$ & 117.0 & 78.2 & $4.174 \pm 0.200$ & $7.963 \times 10^{6}$ & 17.4 & 83.7 & $2.191 \pm 0.087$ \\
\hline & & & & & $4.832 \times 10^{5}$ & 82.7 & 55.4 & $1.341 \pm 0.069$ \\
\hline SG-F5A & $1.848 \times 10^{6}$ & 108.0 & 88.7 & $4.719 \pm 0.247$ & $8.725 \times 10^{6}$ & 16.9 & 95.6 & $2.716 \pm 0.122$ \\
\hline
\end{tabular}

The GPC elution profiles of $A$. senegal are shown in (Fig. 1). The RI profile indicates the A.senegal samples consisted with two main molecular species. The first one corresponding to the minor peak which appeared at the elution volumes of $\sim 7.5 \mathrm{ml}$ represented about $13 \%$ of the total mass. The second one corresponding to the major peak which appeared at the elution volume of $\sim 12.5 \mathrm{ml}(\sim 87 \%)$ of the total mass. The overlay of the elution chromatograms of A.senegal measured by light scattering detector (Fig. 2) illustrate increasing in molecular weight of the sample $\mathrm{SG}_{10-15}$ which obtanied from 10-15 years old tree. The elution profiles obtained by UV(Fig. 3), are very different from the refractive index profile and show three or four molecular mass species for all A.senegal samples. Two of the peaks correspond to peak 1 and 2 observed by refractive index and the relative intensity of each is very

\section{Volume 4 Issue 12, December 2015}




\section{International Journal of Science and Research (IJSR) \\ ISSN (Online): 2319-7064}

Index Copernicus Value (2013): 6.14 | Impact Factor (2014): 5.611

different..However, the elution chromatograms maesured by the refractive index (Fig. 4) is an evident that there is a decrease in the amount of the AG component in the sample $\mathrm{SG}_{10-15}$, which link to give an increase amount of AGP component.

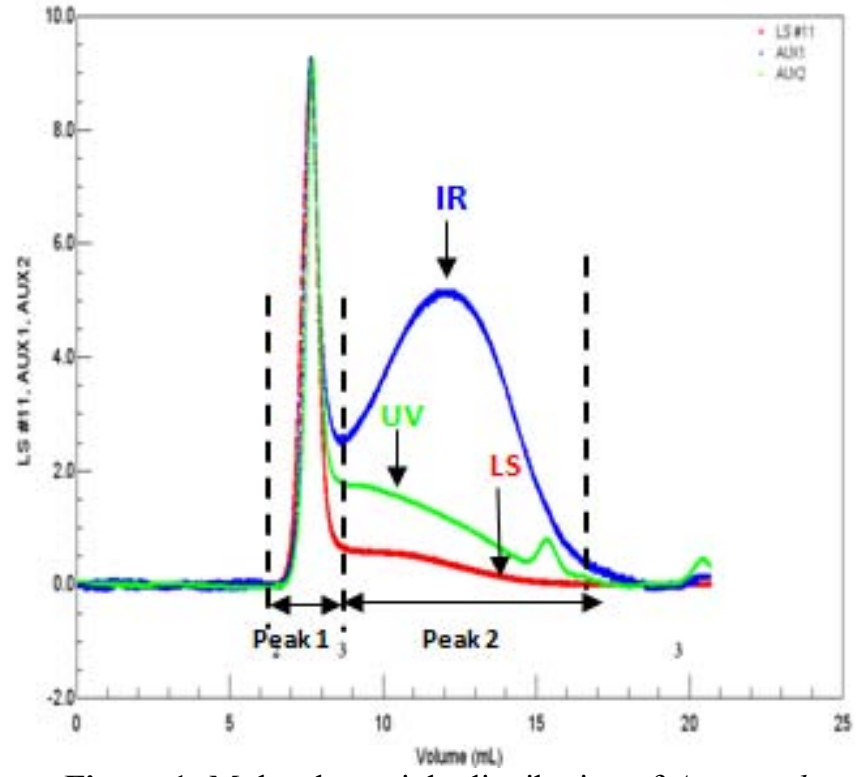

Figure 1: Molecular weight distribution of A.senegal $\mathrm{SG}_{10-15}$

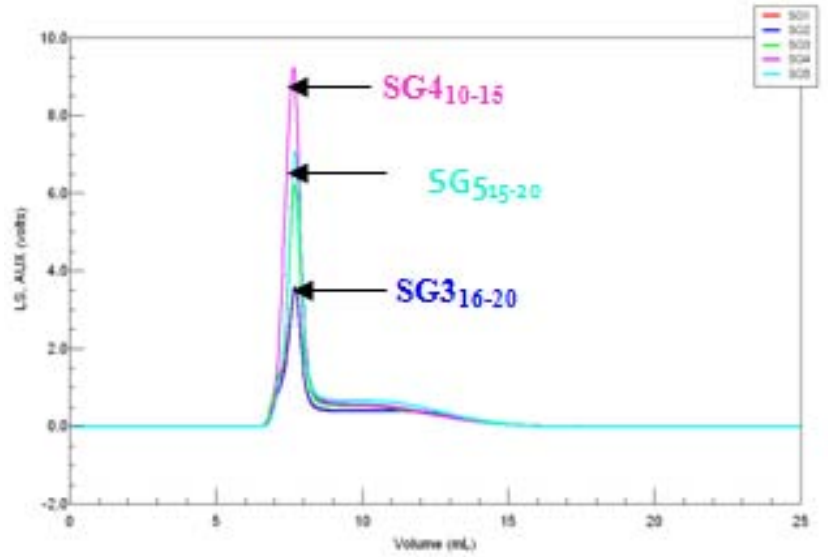

Figure 2: GPC elution profiles of A.senegal using light scattering.

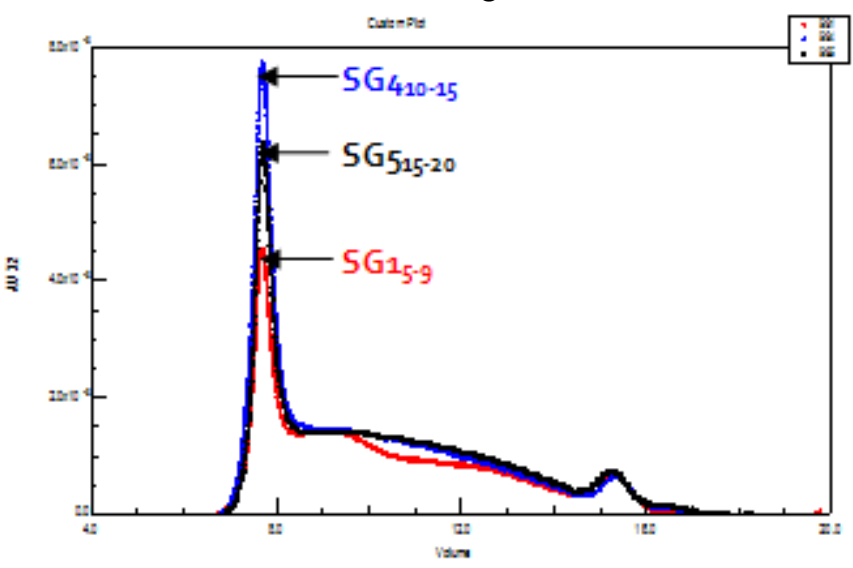

Figure 3: The elution profiles monitored by UV at $214 \mathrm{~nm}$ for the A.senegal samples.

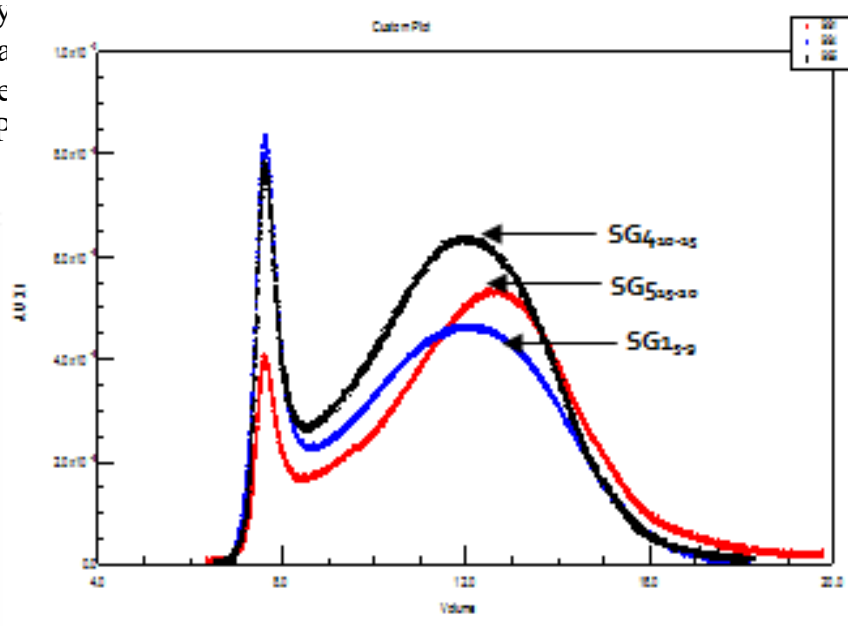

Figure 4: The elution profiles monitored by RI at $214 \mathrm{~nm}$ for the $A$. senegal samples.

\subsection{Emulsification properties and stability of A.senegal and their fractions.}

Emulsification effectiveness was evaluated based on the initial particle size of the emulsions. The emulsions were then subjected to an acceleration testing (stored for 3 days and 7 days at $60{ }^{\circ} \mathrm{C}$ ). Particle size diameter of emulsion after the acceleration test was measured using a particle size distribution analyzer. Emulsification stability was evaluated by the change in particle size of emulsion after acceleration test. The change in particle size after the acceleration test (stored for 7 days at $60{ }^{\circ} \mathrm{C}$ ) was taken as a parameter to designate the category of the gum sample. Therefore, the gum samples which showed a change of $0.1 \mu \mathrm{m}$ or less were classified as category 1 status (good emulsifier). A change $>0.1-1.0 \mu \mathrm{m}$ were classified as category 2 status. The less stable emulsions which showed a change $>1.0 \mu \mathrm{m}$ were allocated category 3 status (poor emulsifier).

The result shows that the less change in particle size diameter was found in $\mathrm{SG}_{10-15}$ sample that picked from 10 15 years old tree. For this reason they can be allocated a grade 1 . On the other hand the volume median diameter of $\mathrm{SG}_{5-9}$ and $\mathrm{SG}_{5-9}$ sample from 5-9 years old tree increased to $200 \%$ and $160 \%$ over the initial volume respectively. Therefore the $\mathrm{SG}_{5-9}$ and $\mathrm{SG}_{5-9}$ did not show good stability and gave a high change in particle size diameter $(0.58$ and $0.29 \mu \mathrm{m}$ ), for this reason allocated a grade 2 status (less stable emulsifier)(Table 5 and Fig. 5).

The volume median diameter of $\mathrm{SG} 3_{16-20}$ and $\mathrm{SG} 5_{16-20}$ sample from 16-20 years old tree increased to $122 \%$ and $108 \%$ over the initial volume respectively. Also the result indicates that the change in particle size diameter of SG3 $16-20$ and SG5 $5_{16-20}$ was 0.098 and $0.045 \mu \mathrm{m}$ respectively. For this reason they can be allocated a grade 1 status, but of less stability than $\mathrm{SG}_{10-15}$ sample. The less change in particle size diameters were found in the sample $\mathrm{SG} 4_{10-15}$ which obtained from 10-15 years old tree, indicating the increase adsorption of the protein on the oil droplet surface and maximum the protein/surface contact and hence reduce the droplet size. This might be promoted by a high viscosity of the continous phase, giving enough time for protein to be 


\section{International Journal of Science and Research (IJSR) \\ ISSN (Online): 2319-7064 \\ Index Copernicus Value (2013): 6.14 | Impact Factor (2014): 5.611}

adsorbed and thus stabilizes the oil droplet surface from coalescence [27].

All ethanol fractions have a less change in particle size than $0.1 \mu \mathrm{m}$, for this reason they can be allocated grade 1 status compared to grade 2 status for the starting material (SGcontrol) (Table 5) and (Fig. 6), these results are largely explained by the association of protein with high molecular fraction AGP as shown in (Fig. 7).

Table 5: Particle size diameter of A.senegal emulsions using a laser diffraction particle size analyzer.

\begin{tabular}{|c|c|c|c|c|}
\hline $\begin{array}{c}\text { Samples } \\
\text { code }\end{array}$ & Grade & $\begin{array}{c}\text { Initial VMD } \\
(\mu \mathrm{m})\end{array}$ & $\begin{array}{c}\text { ATST VMD } \\
(\mu \mathrm{m})\end{array}$ & ESI $(\mu \mathrm{m})$ \\
\hline SG-control & 2 & 0.598 & 0.704 & 0.196 \\
\hline SG1 $_{5-9}$ & 3 & 0.452 & 1.128 & 0.676 \\
\hline SG2 $_{5-9}$ & 2 & 0.475 & 0.784 & 0.289 \\
\hline SG3 $_{16-20}$ & 1 & 0.437 & 0.535 & 0.098 \\
\hline SG4 $_{10-15}$ & 1 & 0.503 & 0.526 & 0.023 \\
\hline SG5 $_{16-20}$ & 1 & 0.551 & 0.596 & 0.045 \\
\hline SG-F1E & 1 & 0.575 & 0.639 & 0.064 \\
\hline SG-F2E & 1 & 0.522 & 0.572 & 0.050 \\
\hline SG-F3E & 1 & 0.844 & 0.890 & 0.046 \\
\hline SG-F4E & 1 & 0.680 & 0.75 & 0.070 \\
\hline SG-F5E & 1 & 0.545 & 0.642 & 0.098 \\
\hline SG-F1A & 1 & 0.696 & 0.718 & 0.022 \\
\hline SG-F2A & 2 & 0.974 & 1.336 & 0.362 \\
\hline SG-F3A & 1 & 0.767 & 0.817 & 0.050 \\
\hline SG-F4A & 2 & 0.755 & 0.863 & 0.108 \\
\hline SG-F5A & 2 & 0.700 & 0.841 & 0.141 \\
\hline
\end{tabular}

*ATST means Accelerated temperature stress test for 7 days at $60{ }^{\circ} \mathrm{C}$.

*ESI means Emulsion Stability Index.

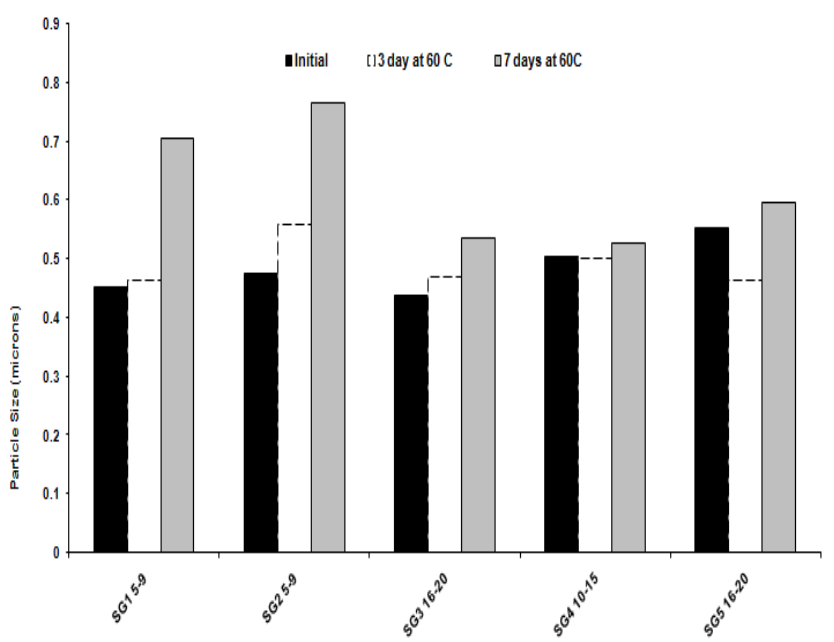

Figure 5: VMD of initial and accelerated of A.senegal emulsions.

Acetone fraction (SG-F1A and SG-F3A) gave the best performance and stability and was significantly better than the starting material (SG-control) (Fig. 8). Fraction (SG-F1A and SG-F3A) showed the high UV response compared to the starting material (Fig. 9) indicating the protein is associated with high molecular weight fraction (AGP). The results showed that it's possible to produce good and stable emulsifier fraction from less emulsifier when the protein distribution is changed and shift to the high molecular fraction (AGP).

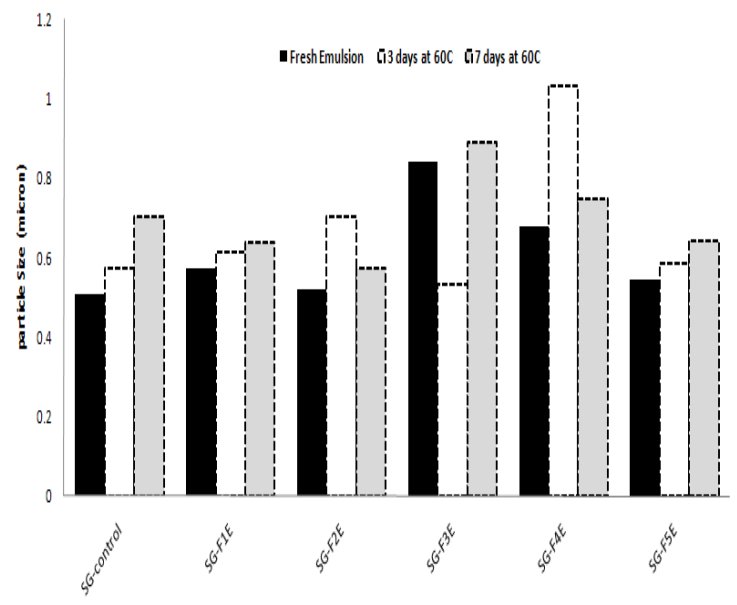

Figure 6: Change in the VMD of initial and accelerated of ethanol fractions of A.senegal emulsions.

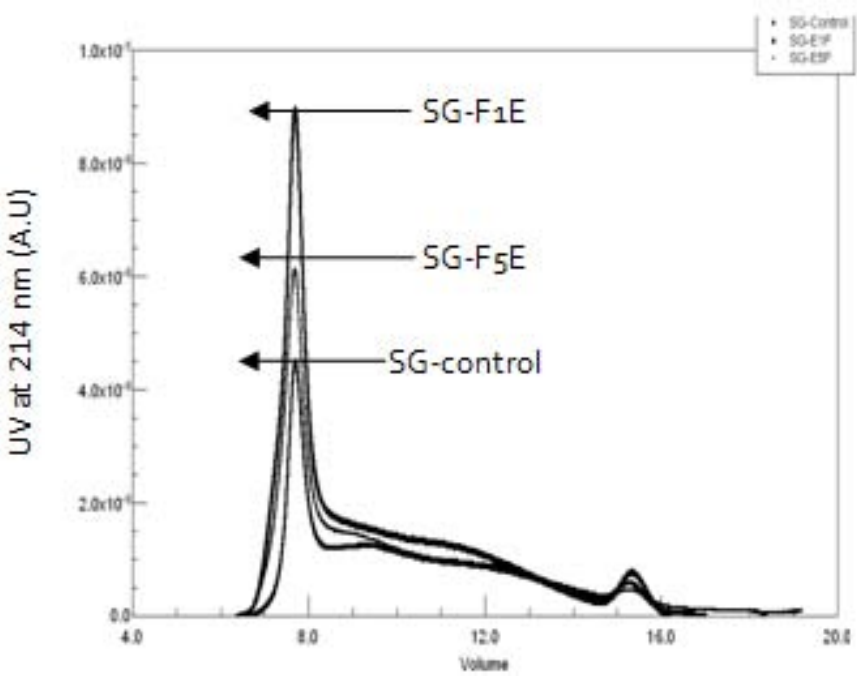

Figure 7: UV profile at $214 \mathrm{~nm}$ of $A$. senegal control andfractions obtained in ethanol.

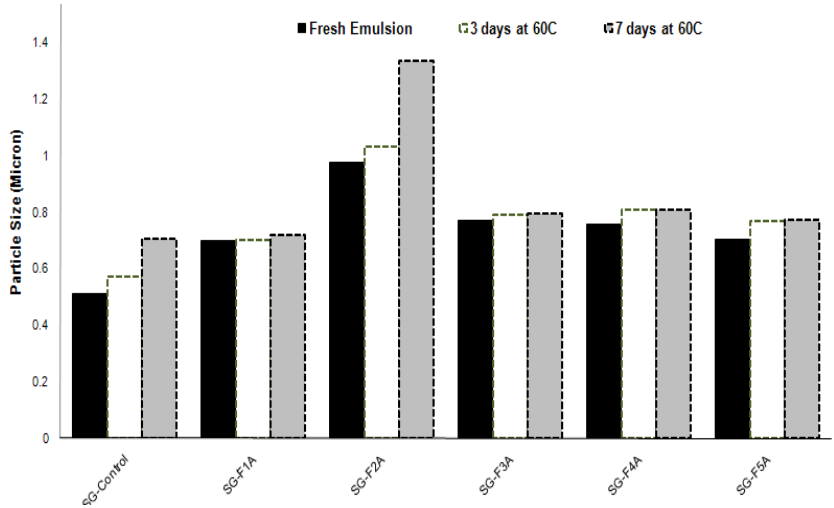

Figure 8: Change in the VMD of initial and accelerated of ethanol fractions of $A$. senegal emulsions. 
International Journal of Science and Research (IJSR)

ISSN (Online): 2319-7064

Index Copernicus Value (2013): 6.14 | Impact Factor (2014): 5.611

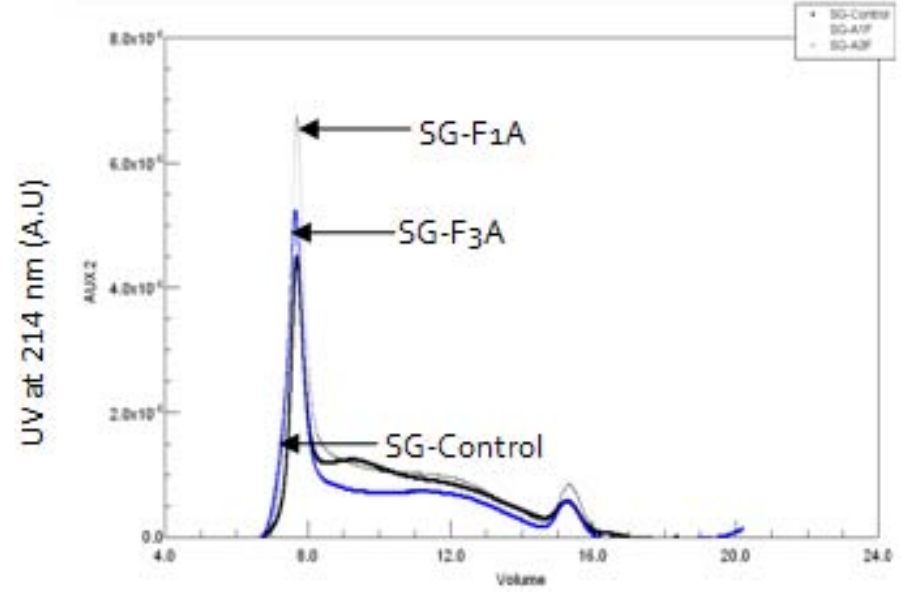

Figure 9: UV profile at $214 \mathrm{~nm}$ of $A$. senegal control and fractions obtained in Acetone.

\section{Conclusion}

Analytical parameters gave different data for the various A.senegal and fractionated samples and these include yield, moisture, ash, $\mathrm{pH}$, specific rotation, intrinsic viscosity, nitrogen and protein contents. The results in this study showthe differences between A.senegal and their fractions and confirm the role of high molecular weight fraction (AGP) as the fraction responsible for the emulsification performance and stability.

\section{Acknowledgements}

I would like to thank Prof Saphwan Al-Assaf (The Glyn O. Phillips Hydrocolloids Research Centre, Glyndwr University, Mold Road. PlasCoch, Wrexham, LL11 2AW, UK) for hosting me in their lap and providing technical support.

\section{References}

[1] P. A. Williams, and G. O. Philips, Foods and Foods ingredient. Journal of Japan., 211 (2006) 181.

[2] S. C. Churms, E. H. Merrified and A. M. Stephen, Carbohydrate Res., 123 (1983) 267- 279.

[3] R. C. Randall, G. O. Phillips and P. A. Williams, Food Hydrocolloids., 3 (1989) 65.

[4] P. A. Williams, G.O. Phillips and A. M. Stephen, Food Hydrocolloids., 4 (1990) 305.

[5] A. Prakash, M. Joseph and M. E. Mangion, Food Hydrocolloids., 4 (1990) 177.

[6] R. R. O. Selvendron and M. A Neill, Encyclopedia of Plant Phisico, New Series., 13A (1982) 515.

[7] M. C. Vandevelde and J. C. Fenyo, Carbohydrate Polymer., 5 (1985) 251- 273.

[8] M. E. Osman, P. A. Williams, A. R. Menzies and G. O. Phillips, J. Agric. Food Chem., 41(1993) 71.

[9] D. M. W. Anderson and J. F. Stoddart, Carbohydrate Res., 6 (1966) 97-103.

[10] S. Cannoly, J. C. Fenyo, and M. C. Vandevelde, Food Hydrocolloids., 1 (1987) 477.

[11] S. Duvallet, J. C. Fenyo and M. C. Vandvelde, Polym. Bull., 21(1989) 517.
[12] O. H. M. Idris, P. A. Williams and G. O. Phillips, Food Hydrocolloids., 12 (1998) 379-388.

[13] S. Al-Assaf, G. O. Philips and P. A. Williams, Food Hydrocolloids., 19 (2005) 661- 667.

[14] R. J. Moakes, A. Sullo and T. Norton, RSCAdv ., 5 (2015) 60786-60795.

[15] J.S. Lim, S. F. Wong, M.C. Law and Y. Samyudia, Journal of Applied Science., 15 (2015) 167-172.

[16] Y. Baoru, Z. Rujing and Y. Ping,Molecules., 20 (2015) 5166.

[17] E. Dickenson and B. G. Vanda, Carbohydrate Polymers, 14 (1991) 385

[18] M. L. Jayme, D. E. Dunstan and M. L. Gee, Food Hydrocolloids., 13 (1999) 459-465.

[19] R. A. Buffo, G. A. Reineccius and G. W. Oehlert, Food Hydrocolloids., 15 (2001) 53-66.

[20] S. Al-Assaf, G. O. Phillips, H. Aoki and Y. Sasaki, Food Hydrocolloids., 21(2007) 319-328.

[21] JECFA. FAO, Compendium of food additive specification, Addendum 3, No. 52 (1965) 83-85. Rome

[22] Encyclopedia of Chemical Technology, Executive and Editor Anthony Stander, inter science, publishers John Willey \& Son. Inc 2 (1966) London.

[23] JECFA. FAO, Specification for identity and purity of certain food Additives, food Nutrition paper., 49 (1990) 23-35. Rome.

[24] M. E. Osman, A. R. Menzies, P. A. Williams and G. O. Phillips, Food Hydrocolloids., 8 (1994) 233-242.

[25] D. M. W. Anderson, M. M. E. Bridgeman, J. G. Farguhar and C. G.A. McNab, Int. tree crops. J., 2 (1983) 245-254

[26] K. A. Karamalla, N. E. Siddig, and M. E. Osman, Food Hydrocolloids., O (1998) 1-6.

[27] N. H. Ibrahim, Y. B. Che man, C. P. Tan and I. N. Aini, Food Hydrocolloids., 23 (2009) 233-243.

[28] D. M. W. Anderson and I. C. M. DeaCarbohydrates Res., 7 (1968) 109-120. 